Article

\title{
An Approach to Assess Sustainable Supply Chain Agility for a Manufacturing Organization
}

\author{
Ayoub Al-Zabidi ${ }^{1}$, Ateekh Ur Rehman ${ }^{1,2, *(\mathbb{D})}$ and Mohammed Alkahtani ${ }^{1,2, *(D)}$ \\ 1 Department of Industrial Engineering, College of Engineering, King Saud University, \\ Riyadh 11421, Saudi Arabia; 439106932@student.ksu.edu.sa \\ 2 Raytheon Chair for Systems Engineering (RCSE Chair), Advanced Manufacturing Institute, \\ King Saud University, Riyadh 11421, Saudi Arabia \\ * Correspondence: arehman@ksu.edu.sa (A.U.R.); moalkahtani@ksu.edu.sa (M.A.); \\ Tel.: +966-11-4679176 (M.A.)
}

Citation: Al-Zabidi, A.; Rehman, A.U.; Alkahtani, M. An Approach to Assess Sustainable Supply Chain Agility for a Manufacturing Organization. Sustainability 2021, 13, 1752. https://doi.org/10.3390/ su13041752

Academic Editors: Juan-José Alfaro-Saiz and Raúl Rodríguez-Rodríguez Received: 31 December 2020 Accepted: 1 February 2021 Published: 6 February 2021

Publisher's Note: MDPI stays neutral with regard to jurisdictional claims in published maps and institutional affiliations.

Copyright: (c) 2021 by the authors. Licensee MDPI, Basel, Switzerland. This article is an open access article distributed under the terms and conditions of the Creative Commons Attribution (CC BY) license (https:// creativecommons.org/licenses/by/ $4.0 /)$.

\begin{abstract}
Worldwide business organizations realize that agility of sustainable supply-chain is a requisite need for survival in a dynamic, competitive, and unpredictable market. The contribution of this research is to explore and evaluate sustainable agility in supply chains for a dairy manufacturing organization located in Saudi Arabia. Other contributions of this research are to update the literature about the different factors contributing to achieve agile supply chain, propose conceptual framework and assessment approach incorporating the relationships between sustainable supply-chain capabilities, enablers, and attributes, and shortlisting the agility barriers and how they would facilitate manufacturing organizations' performance. The paper presents supply chain agility evaluation approach, which covers identification of agile supply-chain capabilities and drivers. It also presents a conceptual model and a framework to define agility level and barriers within the supply-chain. In the paper, fuzzy logic approach is preferred, owing to its capability to incorporate and deal with problems involving impreciseness and vagueness phenomena. Threshold-value in this study for the case organization is set to 0.24829 . The outcome of the adopted approach indicates that 21 attributes performed below the threshold value; these attributes are further categorized as agility barriers. These are the barriers within their supply chain that impact the agility-level. For the case organization, the foremost priority is to enhance maintainability and serviceability to make it flexible and inexpensive to establish an agile responsive supply chain. At the same time, it should have priority to focus on development and integration of their core competencies to deal with cross-functional and cross-enterprise issues in supply chain. For the case organization, the agility level was found "very agile," although it is below the "extremely agile." Thus, a study was developed to understand the behaviour of the supply chain agility and assess/evaluate it to support decision makers in order to develop a strategic solution for different organizational barriers.
\end{abstract}

Keywords: supply chain; strategies; sustainability; agility; agility assessment

\section{Introduction}

In the dynamic, competitive, and unpredictable market, customer demand can be satisfied through different strategies which are related to suppliers, manufacturers, distributors, retailers, and customers, and also get controlled by flows of material, finance, information, and technology [1,2]. To explore competitive base and strategies, business organizations should practice moulding their supply-chain with a knowledge-rich environment and integration of resources. This also helps with understanding the behaviour of supply-chain and developing assessment for supporting decision makers to develop alternative strategies for a specific organizational problem. To cover the previous aspects, supply chain agility has been studied. Agility is capability to quickly-sense and timely-respond to market dynamics and sustainable customers, whereas sustainable agility is the supply chain agility when it is supported at every level of the organization interactions over processes and tools [3]. 
The notion of supply chain agility has been introduced due to parallel developments in the areas of agile systems and manufacturing as well as supply chain management [4]. Initially, it has been defined with respect to the agile enterprise [5], products and workforce [6], capabilities [7], virtual teaming [8], and now with the sustainable environment [9]. The early proponents of agility defined it as a system with exceptional internal capabilities to meet the rapidly changing needs of the market place with speed and flexibility [10]. The internal capacities of the firm include hard and soft technologies, human resources, educated and highly motivated management, and information and communication technologies, while flexibility often implies responding to customer demand almost in real time high responsiveness among product models or between product lines [10]. Subsequently, agility is defined as an ability of an organization to respond rapidly to changes in demand, both in terms of volume and variety [11], and is all about customer responsiveness and market turbulence and need of specific capabilities [8]. Successively, researchers [9,12] defined agile supply chain as an ability to have visibility of demand, flexible and quick response and synchronized operations; and suggested that it can be evaluated with both hard and soft criteria of flexibility, profitability, quality, innovativeness, and proactivity, speed of response, cost, and robustness. Later, in response to dynamic demand, to manage disruption risks and to guarantee uninterrupted services, researchers [13-15] redefined agility that enables an organization to evolve products and services quickly and economically in response to the customers' dynamic demands and, have focused on inducing velocity and flexibility in the supply chain to reduce waste and avoid customer dissatisfaction. They also suggested agility performance measures as product quality, product innovation, and process innovation; all geared towards flexibility and lead time reduction.

Thus, agile sustainable supply chain concerns change, uncertainty, and unpredictability within its business environment and makes appropriate consistent responses to changes. Therefore, an agile sustainable supply chain requires various distinguishing capabilities. These capabilities include four main elements $[3,13,16]$ : responsiveness, which is the ability to identify changes and respond to them quickly, reactively, or proactively, and also to recover from them; competency, which is the ability to efficiently and effectively realize organizational objectives; flexibility, which is the ability to implement different processes and apply different facilities to achieve the same goals; and quickness, which is the ability to complete an activity as quickly as possible.

Modelling of sustainable agile supply chain is a powerful way in order to increase understanding of the behaviour of the supply chain. Such modelling will support decision makers to develop a strategic solution for a specific organizational problem. It is evident that researchers $[13,17]$ have addressed a number of techniques to measure supply chain agility. However, these measurements are described subjectively by linguistic terms which can always be criticized because of the limitations of the scale used to score the supply chain capabilities. Organizations have realized that agility in their supply chain is quite essential for the survival and competitiveness. In the way of implementing agility in a supply chain, the issues to be examined are agility, its measurement, agility level, and barriers [18]; and subsequently agility indexing, which in turn reveals the strategic agile position of an organization in the competitive business environment [19]. It is evident that most of the researchers presented theoretical supply chain agility assessment models and/or approaches $[8,20-22]$ and relevant performance measures contributing to supply chain agility. At the same time, some researchers have focused on investigating the efficacy of these proposed theoretical assessment models via empirical studies $[5,17]$ and real case studies $[23,24]$, and highlight the feasibility and applicability of agility assessment models $[25,26]$.

In our study, when agile sustainable supply chain concept emerged first in context to the Saudi Arabian manufacturing organization, the case organization had many different questions to us, that includes: how to define and measure sustainable agility of supplychain? How to continue sustainable survive in a volatile demand? In order to answer these questions, a lot of knowledge is required in what you want to measure, how you 
will measure it and how you will read and assess the results. To deal with such decisions, an approach in context to Saudi Arabia is proposed after analysing the different factors which are vital to achieve supply-chain agility [27]. Here in the paper, the objective is to propose an assessment approach to quantify the relationships between supply-chain agility capabilities, enablers, and attributes to determine the needed supply-chain agilitylevel. The aim of the study is to verify and validate the proposed approach with a dairy manufacturing organization located in Saudi Arabia. The purpose of the assessment approach is to estimate agility of their supply chain and analyse barriers within their supply-chain to be able to sense required changes and respond quickly and relevantly.

This paper includes six sections. This section is followed by Section 2 where brief reviews to different important capabilities, enablers, and attributes of supply-chain agility evaluation is presented. Subsequently, in Section 3, the organization case study details and proposed approach for assessing supply-chain agility are presented. The application of the proposed approach to assess sustainable supply chain agility for a manufacturing organization is presented in Section 4 . Sections 5 and 6 are the managerial discussion, the main findings, the limitations of the adopted approach, and recommendations for other researchers are discussed and concluded.

\section{Supply Chain Sustainable Agility Evaluation: A Brief Review}

To help decision makers better achieve sustainable agile supply chain, different studies have attempted to assess an organization's agility. It is evident that initially researchers $[5,17,28-33]$ evaluated supply chain performance statistically by integrating the questionnaire data and subjective approach, and rank performance enablers of supply chain that are collected from different business professionals. Subsequently, others [34-41] suggested to integrate multiple criterions related to production, market, people, and information to evaluate the performance of supply chain. For example, researchers used the technique of preference by similarity index multi-criteria approach [42-48], generalized trapezoidal approach $[44,45]$, data envelopment analysis $[46,47]$, set theory $[9,24]$, agent based modelling [9], and quality-function deployment [49]. Vinodh and Aravindraj [40] suggested strategies and responsibilities related to workforce and technology to evaluate supply chain performance. Sreenivasa et al. [39] proposed different ways to identify weak criteria of supply chain and overcome them by embracing the latest technological advancements. Recently, researchers [13,16] emphasize practices to increase workforce quickness, and sustainable performance to minimize damage to the environment.

To assess the supply chain agility performance, researchers adopted multiple approaches. Considering the literature over the past 10 years, the selective adopted assessment approaches and their focus are highlighted in Table 1.

Table 1. Assessment Approaches for Agile Supply Chain.

\begin{tabular}{|c|c|}
\hline Models & Focused On \\
\hline Structural equation model [50] & Quickness in the plan, source, make, and deliver capacity of the supply chain \\
\hline Conceptual model [51] & $\begin{array}{l}\text { Impact of the relationship between supply chain competence and supply } \\
\text { chain agility }\end{array}$ \\
\hline Delphi model [31] & Used to develop a series of weighted agile supply chain management practices \\
\hline $\begin{array}{l}\text { Flexible infrastructure and assimilation } \\
\text { model [52] }\end{array}$ & $\begin{array}{l}\text { A model to examine how flexible infrastructure and assimilation affect supply } \\
\text { chain agility }\end{array}$ \\
\hline Graph theory model [53] & $\begin{array}{l}\text { Assess supply chain agility aspects to achieve market share even during } \\
\text { a disruption }\end{array}$ \\
\hline Analytic network process model [20] & $\begin{array}{l}\text { It provides a systematic approach to explore and analyse influential relationships } \\
\text { between agile-enabling factors }\end{array}$ \\
\hline Grey-based decision-making model [54] & To evaluate the cause and effect relationships of agile-supply enabling factors \\
\hline
\end{tabular}


Table 1. Cont.

\begin{tabular}{cc}
\hline Models & Focused On \\
\hline Closed-loop analytical network model [24] & Is proposed to deal with the complex interrelationships among the supply chain \\
agility aspects and attributes
\end{tabular}

Thus, it is also evident that researchers in supply chain have proposed different models and approaches for assessing supply chain agility in different case organization. The contribution of our study is to update the literature about the different factors contributing to achieve a sustainable agile supply chain and propose conceptual framework and assessment approach investigating the associations between capabilities, enablers, and attributes to determine the needed agility level and how to facilitate the organization's performance.

Based on the review of the various assessment approaches for supply chain $[13,14,16,59]$, fuzzy logic approach was highly preferred by researchers owing to its capability to incorporate and deal with problems involving impreciseness and vagueness phenomena. From literature, it is evident that researches adopted fuzzy multi-criteria decision-making methods in numerous sectors; for example: to assess sustainability of small urban neighbourhoods [60] and resilience of urban communities [61]; to locate supply chain logistic centres [62]; analysing safety hazards and occupational risks [63]; ranking alternative construction project plans [64] and renewable energy parks [65]; selection of material in the design and fabrication process [66]. The disadvantages of other approaches as that they are inflexible and must be restructured to appropriate the prevailing new circumstances as they involve several levels of linguistic terms or different membership functions usage. In addition, some of these approaches are complex mathematical equations that are challenging to solve manually. The organization case studied proposed an approach for assessing supply-chain agility. Its application and the drawn inferences are presented here in the following sections.

\section{Evaluating Supply Chain Agility: A Case Study}

The case study is one of the largest manufacturer and vertically integrated as distributor of fresh dairy products to over retailers across Arab countries. In most recent years, the organization has expanded its scope to enter different regional and international areas and to invest in farmland. It is evident that large multinationals organizations have sought to provide both local and global dynamic response to an uncertain business environment. Moreover, because of dynamic customer requirements, the organization has found it increasingly difficult to ensure consistent growth.

To evaluate supply-chain agility of the largest manufacturer and distributor, the framework of the proposed approach has seven steps; each of which are illustrated here below; broadly, they are categories in three main phases. Phase I involves examination of the organization business operation environment and identification of agility enablers and attributes to develop the agility conceptual model. Phase II is a frame of the methodology to assess and synthesize the listed agility-enablers and agility-attributes contribution, for the purpose of obtaining supply chain agility index. Subsequently, in Phase III, the agilityindex is matched with a suitable linguistic term to determine the supply-chain agilitylevel. Phase III calculates the performance index for each attribute of supply-chain for the 
purpose of picking out major barriers to enable decision makers to respond effectively and implement corrective measures. The framework of the proposed approach consists of four capabilities, six enablers, and 93 attributes as presented in the below Figure 1.The enablers and corresponding attributes are listed here below (refer Table 2).

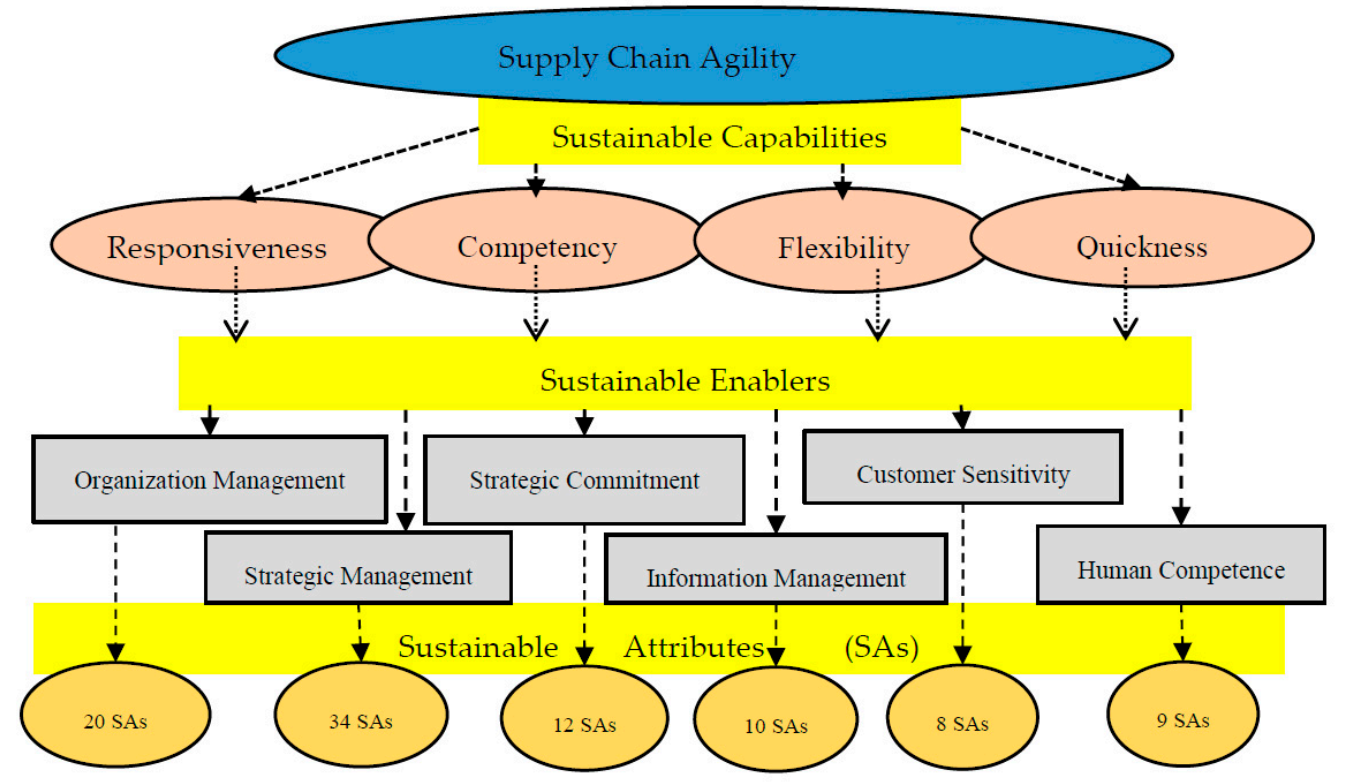

Figure 1. Supply-chain agility conceptual model.

Table 2. Sustainable Enablers and Attributes for evaluating supply chain agility.

\begin{tabular}{|c|c|c|c|c|c|c|}
\hline $\begin{array}{l}\text { Sustainable } \\
\text { Enablers }\end{array}$ & $\#$ & $\begin{array}{l}\text { Sustainable } \\
\text { Attributes }\end{array}$ & References & $\#$ & $\begin{array}{l}\text { Sustainable } \\
\text { Attributes }\end{array}$ & References \\
\hline \multirow{10}{*}{$\begin{array}{l}\text { Organization } \\
\text { Management }\end{array}$} & 1 & $\begin{array}{l}\text { Material planning and } \\
\text { control }\end{array}$ & {$[14,19,67]$} & 11 & $\begin{array}{c}\text { Digitalization in product } \\
\text { design }\end{array}$ & {$[13,14,68-70]$} \\
\hline & 2 & $\begin{array}{l}\text { Integrated logistic } \\
\text { networks }\end{array}$ & {$[1,14,19,60]$} & 12 & $\begin{array}{l}\text { Digitalization in } \\
\text { outsourcing }\end{array}$ & {$[7,14,20]$} \\
\hline & 3 & $\begin{array}{l}\text { Virtual logistics } \\
\text { networks }\end{array}$ & {$[7,14,19,71]$} & 13 & $\begin{array}{c}\text { Digitalization in reverse } \\
\text { logistics }\end{array}$ & {$[1,14,60,61,63]$} \\
\hline & 4 & Innovative organization & {$[26,41,61,62]$} & 14 & Building stronger team & {$[13,14,61,64]$} \\
\hline & 5 & Organizational structure & {$[13,14,19,61,62]$} & 15 & $\begin{array}{c}\text { Compatible personnel } \\
\text { development }\end{array}$ & {$[13,14,61,62,64]$} \\
\hline & 6 & Distribution networks & {$[7,14,67,68]$} & 16 & Team decision making & {$[13,14,16,61,64]$} \\
\hline & 7 & $\begin{array}{c}\text { Integrated } \\
\text { manufacturing network }\end{array}$ & {$[1,13,14,67,68]$} & 17 & $\begin{array}{l}\text { Manufacturing } \\
\text { capabilities }\end{array}$ & {$[1,14,61,68]$} \\
\hline & 8 & $\begin{array}{l}\text { Warehousing } \\
\text { management }\end{array}$ & {$[14,67-69]$} & 18 & $\begin{array}{l}\text { Technological } \\
\text { capabilities }\end{array}$ & {$[1,13,14,61,63]$} \\
\hline & 9 & $\begin{array}{l}\text { Order fulfilment } \\
\text { strategies }\end{array}$ & {$[1,13,14,67-69]$} & 19 & $\begin{array}{l}\text { Cooperating with } \\
\text { companies }\end{array}$ & {$[14,60-62]$} \\
\hline & 10 & $\begin{array}{l}\text { Digitalization of supply } \\
\text { chain }\end{array}$ & {$[13,14,16,67,68,70]$} & 20 & $\begin{array}{l}\text { Demand of supply } \\
\text { planning }\end{array}$ & {$[1,13,14,61]$} \\
\hline
\end{tabular}


Table 2. Cont.

\begin{tabular}{|c|c|c|c|c|c|c|}
\hline $\begin{array}{l}\text { Sustainable } \\
\text { Enablers }\end{array}$ & $\#$ & $\begin{array}{l}\text { Sustainable } \\
\text { Attributes }\end{array}$ & References & $\#$ & $\begin{array}{l}\text { Sustainable } \\
\text { Attributes }\end{array}$ & References \\
\hline \multirow{17}{*}{$\begin{array}{c}\text { Strategic } \\
\text { Management }\end{array}$} & 1 & Innovative infrastructure & {$[7,14,20,68]$} & 18 & $\begin{array}{c}\text { Corporate and business } \\
\text { strategies }\end{array}$ & {$[14,68,69,72]$} \\
\hline & 2 & $\begin{array}{l}\text { Cross functional } \\
\text { integration }\end{array}$ & {$[20,73,74]$} & 19 & Streamlining of processes & {$[14,68,69]$} \\
\hline & 3 & $\begin{array}{l}\text { Participative } \\
\text { management }\end{array}$ & {$[14,20,68]$} & 20 & Excellent communication & {$[14,20,67,68]$} \\
\hline & 4 & $\begin{array}{c}\text { Synchronized material } \\
\text { movement }\end{array}$ & {$[7,14,20,68]$} & 21 & $\begin{array}{c}\text { Proper scheduling of } \\
\text { activities }\end{array}$ & {$[13,14,68]$} \\
\hline & 5 & $\begin{array}{l}\text { Effective training } \\
\text { environment }\end{array}$ & {$[14,67,68]$} & 22 & Effective serviceability & {$[14,68,69]$} \\
\hline & 6 & $\begin{array}{l}\text { Well-defined procedures } \\
\text { and forms }\end{array}$ & {$[7,14,67,68]$} & 23 & Organizational culture & {$[20]$} \\
\hline & 7 & $\begin{array}{l}\text { Flexible software for } \\
\text { agility }\end{array}$ & {$[7,14,61]$} & 24 & Pull production system & {$[1,14,68]$} \\
\hline & 8 & $\begin{array}{l}\text { Data management } \\
\text { framework }\end{array}$ & {$[14,68,69]$} & 25 & Parallel operations & {$[14,67,68]$} \\
\hline & 9 & $\begin{array}{l}\text { Product design at least } \\
\text { price }\end{array}$ & {$[20,68,75,76]$} & 26 & $\begin{array}{c}\text { Effective utilization of } \\
\text { time }\end{array}$ & {$[14,68,69]$} \\
\hline & 10 & Supply chain mapping & {$[1,14,20,77]$} & 27 & Strategic SCM network & {$[14,16,20,68,69]$} \\
\hline & 11 & Rapid decision making & {$[14,16,20,68]$} & 28 & $\begin{array}{l}\text { Quality ensured at every } \\
\text { stage }\end{array}$ & {$[13,14,67,68]$} \\
\hline & 12 & $\begin{array}{l}\text { Top management } \\
\text { commitment }\end{array}$ & {$[1,14,67,68]$} & 29 & Zero-inventory system & {$[1,14,68]$} \\
\hline & 13 & $\begin{array}{c}\text { Meeting management } \\
\text { goal }\end{array}$ & {$[14,68]$} & 30 & $\begin{array}{l}\text { Time compression } \\
\text { technologies }\end{array}$ & {$[14,67,68]$} \\
\hline & 14 & $\begin{array}{l}\text { Effective communication } \\
\text { to employee }\end{array}$ & {$[14,20,68]$} & 31 & $\begin{array}{l}\text { Product development } \\
\text { methods }\end{array}$ & {$[7,14,20,68,78]$} \\
\hline & 15 & $\begin{array}{l}\text { Effective short range } \\
\text { planning }\end{array}$ & {$[13,14,20,68,69]$} & 32 & Producing new product & {$[13,14,20,67-69]$} \\
\hline & 16 & Customer delight & {$[14,68,79]$} & 33 & $\begin{array}{l}\text { Value-based purchasing } \\
\text { initiatives }\end{array}$ & {$[14,68,69]$} \\
\hline & 17 & $\begin{array}{c}\text { Transparent information } \\
\text { sharing }\end{array}$ & {$[13,14,68,69]$} & 34 & Quality design & {$[14,68,79]$} \\
\hline \multirow{6}{*}{$\begin{array}{c}\text { Strategic } \\
\text { Commitment }\end{array}$} & 1 & Selection of suppliers & {$[13,20]$} & 7 & Supplier negotiation & {$[1,13,14,68]$} \\
\hline & 2 & $\begin{array}{c}\text { Concurrent execution } \\
\text { activities }\end{array}$ & {$[1,13,14,68]$} & 8 & $\begin{array}{l}\text { Recognizing core agile } \\
\text { capabilities }\end{array}$ & {$[20,26,73,80]$} \\
\hline & 3 & Interlinking departments & {$[1,13,14,68]$} & 9 & $\begin{array}{l}\text { Interpreting business } \\
\text { environment }\end{array}$ & {$[20,26,73,80]$} \\
\hline & 4 & $\begin{array}{l}\text { Networking with } \\
\text { partners }\end{array}$ & {$[1,7,13,14,68]$} & 10 & $\begin{array}{l}\text { Integration of core } \\
\text { competencies }\end{array}$ & {$[4,20,51]$} \\
\hline & 5 & $\begin{array}{c}\text { Build a sustainable agile } \\
\text { culture }\end{array}$ & {$[20,81]$} & 11 & $\begin{array}{l}\text { Integrate intellectual } \\
\text { assets }\end{array}$ & {$[16,20,80]$} \\
\hline & 6 & $\begin{array}{l}\text { Associate trust and } \\
\text { competence }\end{array}$ & {$[1,4,14,20,68]$} & 12 & $\begin{array}{c}\text { Integration of marketing } \\
\text { network }\end{array}$ & {$[20,80,81]$} \\
\hline
\end{tabular}


Table 2. Cont.

\begin{tabular}{|c|c|c|c|c|c|c|}
\hline $\begin{array}{l}\text { Sustainable } \\
\text { Enablers }\end{array}$ & $\#$ & $\begin{array}{l}\text { Sustainable } \\
\text { Attributes }\end{array}$ & References & $\#$ & $\begin{array}{l}\text { Sustainable } \\
\text { Attributes }\end{array}$ & References \\
\hline \multirow{5}{*}{$\begin{array}{l}\text { Information } \\
\text { Management }\end{array}$} & 1 & $\begin{array}{c}\text { Digitalization of demand } \\
\text { information }\end{array}$ & {$[20,74,80,81]$} & 6 & World Wide Web & {$[14,68,69]$} \\
\hline & 2 & $\begin{array}{l}\text { Identifying and } \\
\text { collecting records }\end{array}$ & {$[20,74,80]$} & 7 & $\begin{array}{c}\text { Incorporating } \\
\text { radio-frequency } \\
\text { identification technology }\end{array}$ & {$[13,14,68,82]$} \\
\hline & 3 & Efficient funds transfer & {$[7,14,68]$} & 8 & $\begin{array}{l}\text { Response time to } \\
\text { customer }\end{array}$ & {$[13,14,18,20,68]$} \\
\hline & 4 & $\begin{array}{c}\text { Digitization of partners' } \\
\text { feedback }\end{array}$ & {$[20,81]$} & 9 & Multimedia utilization & {$[14,68,83]$} \\
\hline & 5 & $\begin{array}{l}\text { Information accessibility } \\
\text { dimensions }\end{array}$ & {$[20,74,80,81]$} & 10 & $\begin{array}{c}\text { Early disturbances } \\
\text { detection }\end{array}$ & {$[20,80,81]$} \\
\hline \multirow{4}{*}{$\begin{array}{l}\text { Customer } \\
\text { Sensitivity }\end{array}$} & 1 & $\begin{array}{l}\text { Customer-based } \\
\text { performance }\end{array}$ & {$[14,68,69,76]$} & 5 & $\begin{array}{l}\text { Acceleration of product } \\
\text { release }\end{array}$ & {$[20,80]$} \\
\hline & 2 & $\begin{array}{l}\text { Customer driven } \\
\text { manufacturing }\end{array}$ & {$[14,68,69]$} & 6 & $\begin{array}{l}\text { Create sustainable } \\
\text { customer values }\end{array}$ & {$[14,68,69]$} \\
\hline & 3 & Market trend analysis & {$[13,14,68,69]$} & 7 & $\begin{array}{l}\text { Effective forecasting } \\
\text { method }\end{array}$ & {$[13,14,67-69]$} \\
\hline & 4 & $\begin{array}{l}\text { Modular products } \\
\text { structure }\end{array}$ & {$[20,81]$} & 8 & $\begin{array}{l}\text { Universalization of } \\
\text { customers }\end{array}$ & {$[20,80,81]$} \\
\hline \multirow{5}{*}{$\begin{array}{c}\text { Human } \\
\text { Competence }\end{array}$} & 1 & $\begin{array}{l}\text { Employees involvement } \\
\text { in decision }\end{array}$ & {$[20,80]$} & 6 & $\begin{array}{l}\text { Meeting organization } \\
\text { requirements }\end{array}$ & {$[20,74,81]$} \\
\hline & 2 & $\begin{array}{c}\text { Embrace to market } \\
\text { dynamics }\end{array}$ & {$[20,80]$} & 7 & Evaluating performance & {$[20,74,81]$} \\
\hline & 3 & $\begin{array}{l}\text { Participation in strategy } \\
\text { formulation }\end{array}$ & {$[20,80,81]$} & 8 & Revising strategies & {$[20,74,81]$} \\
\hline & 4 & Identifying opportunities & {$[20,80,81]$} & 9 & $\begin{array}{l}\text { Manage resistance to } \\
\text { change }\end{array}$ & {$[20,74,81]$} \\
\hline & 5 & Handling resources kink & {$[20,80,81]$} & & & \\
\hline
\end{tabular}

\section{Proposed Approach in Phases}

Phase I: Examination of the organization business operation environment and identification of agility enablers and attributes; their weights and performance ratings to achieve sustainable supply chain (Steps 1-3).

Step 1: Identification of Agility-Capabilities, Enablers, and Attributes via Survey

To prepare for supply-chain agility assessment, the evaluators in the organization must survey challenges in the business environment and identify supply-chain performance evaluation criterions. So, the number of experts at the case organization were surveyed to identify agility-capabilities, agility-enablers, and attributes. In addition, we referred to the literature that is related to the evaluation of supply-chain agility [27], and a comprehensive conceptual model is proposed (refer to Figure 1). The conceptual model is divided into three interrelated levels. The first level includes agile supply chain capabilities. These capabilities are measured through different enablers which are included in the subsequent second level. Finally, each enabler is divided into multiple attributes which are included in the last level. Thus, supply-chain agility conceptual model for the case organization consists of four capabilities, six enablers, and 93 attributes are as listed in the above Table 2. 


\section{Step 2: Setting of Ratings, Weights, and Corresponding Fuzzy-Set}

After identifying competences and drivers of agile supply-chain, agility assessment scale is set using fuzzy logic through linguistic assessment and translation. It is almost impractical to directly assign weights and performance ratings to vague agility drivers; therefore, linguistic terms are used in the proposed process. For the purpose of assigning weights and performance ratings to identified agility-capabilities, agility-enablers, and agility-attributes, the assessment scale is adopted and fixed. For the assessment scale and corresponding fuzzy numbers, refer to Table $3[14,78]$.

Table 3. Ratings, Weights, and Fuzzy-Set.

\begin{tabular}{cc}
\hline Performance Ratings (R) & Weights Assigned (W) \\
Linguistic Word: Fuzzy Set & Linguistic Word: Fuzzy Set \\
\hline Worst: $(0.00,0.05,0.15)$ & Very low: $(0.00,0.05,0.15)$ \\
Very poor: $(0.10,0.20,0.30)$ & Low: $(0.10,0.20,0.30)$ \\
Poor: $(0.20,0.35,0.50)$ & Fairly low: $(0.20,0.35,0.50)$ \\
Fair: $(0.30,0.50,0.70)$ & Average: $(0.30,0.50,0.70)$ \\
Good: $(0.50,0.65,0.80)$ & Fairly high: $(0.50,0.65,0.80)$ \\
Very good: $(0.70,0.80,0.90)$ & High: $(0.70,0.80,0.90)$ \\
Excellent: $(0.85,0.95,1.00)$ & Very high: $(0.85,0.95,1.00)$ \\
\hline
\end{tabular}

In order to assess performance ratings and level of weights assigned to supply chain enablers and attributes in the case organization, a team of a number of cross-functional experts was formed at the case organization. These experts represent the heads of various departments within the organization with more than ten years work experience so that they are well aware about the working culture of the organization and its supply chain. The expert members included the planning manager, purchasing manager and purchasing team leader, warehousing manager, design manager, production manager, quality control manager, customer service manager, and a supply chain specialist. Since the number of experts in previous published literature ranges between four to seven experts [13-16,19,59], nine experts were approached and were asked to respond questionnaire based data sheet in the form of linguistic terms. These experts' linguistic responses are converted into fuzzy numbers.

\section{Step 3: Fuzzy Ratings and Fuzzy Weights Computation}

Several indicators were proposed to synthesize and aggregate multiple decision maker's evaluations like arithmetic mean, median, and mode. Here in this paper, we adopted the arithmetic mean to aggregate the evaluations of multiple organization experts. For given enabler $\mathrm{i}(\mathrm{i} \in \mathrm{m})$, fuzzy performance rating $\left(\mathrm{R}_{\mathrm{j}}\right)$ and weight $\left(\mathrm{W}_{\mathrm{j}}\right)$ for each attribute $\mathrm{j}(\mathrm{j} \in \mathrm{n})$ are computed using the below Equations (1) and (2) [13,16], individually.

$$
\begin{gathered}
\mathrm{R}_{\mathrm{j}} \equiv\left(\frac{\sum_{\mathrm{r}=1}^{1} \mathrm{a}_{\mathrm{rj}}}{1}, \frac{\sum_{\mathrm{r}=1}^{1} \mathrm{~b}_{\mathrm{rj}}}{1}, \frac{\sum_{\mathrm{r}=1}^{l} \mathrm{c}_{\mathrm{rj}}}{1}\right)_{\mathrm{i}} \equiv\left(\mathrm{a}_{\mathrm{j}}, \mathrm{b}_{\mathrm{j}}, \mathrm{c}_{\mathrm{j}}\right)_{\mathrm{i}} \\
\mathrm{W}_{\mathrm{j}} \equiv\left(\frac{\sum_{\mathrm{r}=1}^{1} \mathrm{x}_{\mathrm{rj}}}{1}, \frac{\sum_{\mathrm{r}=1}^{1} \mathrm{y}_{\mathrm{rj}}}{1}, \frac{\sum_{\mathrm{r}=1}^{1} \mathrm{z}_{\mathrm{rj}}}{1}\right)_{\mathrm{i}} \equiv\left(\mathrm{x}_{\mathrm{j}}, \mathrm{y}_{\mathrm{j}}, \mathrm{z}_{\mathrm{j}}\right)_{\mathrm{i}}
\end{gathered}
$$

Similarly, for given enabler $\mathrm{i}(\mathrm{i} \in \mathrm{m}$ ), each enabler weight is derived using Equation (3).

$$
\mathrm{W} \equiv\left(\frac{\sum_{\mathrm{r}=1}^{\mathrm{l}} \mathrm{x}_{\mathrm{ir}}}{1}, \frac{\sum_{\mathrm{r}=1}^{\mathrm{l}} \mathrm{y}_{\mathrm{ir}}}{1}, \frac{\sum_{\mathrm{r}=1}^{\mathrm{l}} \mathrm{z}_{\mathrm{ir}}}{1}\right) \equiv(\mathrm{x}, \mathrm{y}, \mathrm{z})_{\mathrm{i}}
$$

For the case organization, the computation of fuzzy performance rating and weight for supply chain agility enabler "organization management" $(i=1)$ and supply chain attribute "Material planning" $(\mathrm{j}=1)$ are presented here below. 
Fuzzy performance rating $\left(\mathrm{R}_{1}\right)$ of the agile supply chain attribute titled "Material planning" is calculated as (refer to Equation (1)). Similarly, for the same attribute $(j=1)$, the fuzzy weight $W_{1}$ is calculated as (refer to Equation (2))

$$
\begin{aligned}
& \mathrm{R}_{1}=\left(\frac{0.20+0.85+. .+0.30}{9}, \frac{0.35+0.95+. .+0.50}{9}, \frac{0.50+1.00+. .+0.70}{9}\right)=(0.47,0.62,0.76)_{1} \\
& \mathrm{~W}_{1}=\left(\frac{0.30+0.30+. .+0.30}{9}, \frac{0.50+0.50+. .+0.50}{9}, \frac{0.70+0.70+. .+0.70}{9}\right)=(0.52,0.67,0.81)_{1}
\end{aligned}
$$

The fuzzy weight for the agile supply chain enabler $(i=1)$ "organization management" is calculated as (refer to Equation (3))

$$
\mathrm{W}=\left(\frac{0.30+0.30+. .+0.20}{9}, \frac{0.50+0.50+. .+0.35}{9}, \frac{0.70+0.70+. .+0.50}{9}\right)=(0.44,0.60,0.76)_{1}
$$

Applying the above computations, for each enabler i, fuzzy weights $\left(\mathrm{W}_{\mathrm{i}}\right)$ are computed and highlighted in Table 4 , and for each attribute $j$, fuzzy performance ratings $\left(R_{j}\right)$ and fuzzy weights $\left(\mathrm{W}_{\mathrm{j}}\right)$ are estimated.

Table 4. Fuzzy weights for each enabler.

\begin{tabular}{ccc}
\hline $\mathbf{i}$ & Sustainable Enablers & $\mathbf{W} \approx(x, y, z)_{i}$ \\
\hline 1 & Organization Management & $(0.44,0.60,0.76)_{1}$ \\
2 & Strategic Management & $(0.56,0.70,0.83)_{2}$ \\
3 & Strategic Commitment & $(0.50,0.65,0.80)_{3}$ \\
4 & Information Management & $(0.58,0.72,0.84)_{4}$ \\
5 & Customer Sensitivity & $(0.44,0.60,0.74)_{5}$ \\
6 & Human Competence & $(0.50,0.65,0.80)_{6}$ \\
\hline
\end{tabular}

Phase II: Assessment and synthesizing the Phase I listed enablers and attributes contribution in the supply-chain, for the purpose of obtaining agility-index (steps 4 and 5). Step 4: Computation of Agility Indices for Each Enabler

For each agility enabler and corresponding multiple attributes, it is important to consolidate the fuzzy ratings and weights, and it is represented by an overall fuzzy agility index for each enabler, and that is further used to determine the organization's overall agility-level. Using a weighted approach, refer to Equation (4) $[13,84,85]$. Fuzzy agility index (FAI) is computed for each enabler $(\mathrm{i} \in \mathrm{m})$.

$$
\mathrm{FAI} \equiv\left(\frac{\sum_{j=1}^{\mathrm{n}}\left(\mathrm{x}_{\mathrm{j}} \times \mathrm{a}_{\mathrm{j}}\right)}{\sum_{j=1}^{\mathrm{n}} \mathrm{x}_{\mathrm{j}}}, \frac{\sum_{\mathrm{j}=1}^{\mathrm{n}}\left(\mathrm{y}_{\mathrm{j}} \times \mathrm{b}_{\mathrm{j}}\right)}{\sum_{j=1}^{\mathrm{n}} \mathrm{y}_{\mathrm{j}}}, \frac{\sum_{\mathrm{j}=1}^{\mathrm{n}}\left(\mathrm{z}_{\mathrm{j}} \times \mathrm{c}_{\mathrm{j}}\right)}{\sum_{j=1}^{\mathrm{n}} \mathrm{z}_{\mathrm{j}}}\right)_{\mathrm{i}} \equiv(\mathrm{d}, \mathrm{e}, \mathrm{f})_{\mathrm{i}}
$$

For the case organization, the overall fuzzy agility-index (FAI) at the enabler "organization management" $(\mathrm{j}=1)$ is calculated as (refer to Equation (4)).

$$
\mathrm{FAI}=\left(\begin{array}{l}
\frac{(0.52 \times 0.47)+(0.52 \times 0.42)+\cdots+(0.56 \times 0.44)}{0.52+0.52+\cdots+0.56}, \\
\frac{(0.67 \times 0.617)+(0.67 \times 0.58+\cdots+\cdots+(0.70 \times 0.60)}{0.67+0.67+\cdots+0.70}, \\
\frac{(0.81 \times 0.76)+(0.811 \times 0.74)+\cdots+(0.833 \times 0.76)}{0.81+0.81+\cdots+0.83}
\end{array}\right)=(0.49,0.64,0.78)_{1}
$$

Using the above computational approach, the agility indices pertaining to the case organization supply chain agility enablers are computed and highlighted in Table 5. 
Table 5. Agility indices for each enabler.

\begin{tabular}{ccc}
\hline $\mathbf{i}$ & Sustainable Enablers & $\mathbf{F A I} \approx(\boldsymbol{d}, \boldsymbol{e}, \boldsymbol{f})_{\boldsymbol{i}}$ \\
\hline 1 & Organization Management & $(0.49,0.64,0.78)_{1}$ \\
2 & Strategic Management & $(0.55,0.69,0.82)_{2}$ \\
3 & Strategic Commitment & $(0.52,0.66,0.81)_{3}$ \\
4 & Information Management & $(0.52,0.66,0.81)_{4}$ \\
5 & Customer Sensitivity & $(0.57,0.71,0.84)_{5}$ \\
6 & Human Competence & $(0.58,0.71,0.84)_{6}$ \\
\hline
\end{tabular}

\section{Step 5: Computation of Supply Chain Agility Fuzzy Index}

Making use of agility indices for each enabler's (refer to above Table 5) supply chain agility fuzzy index (SCAFI) is computed as below (refer Equation (5)):

Supply chain agility fuzzy index $(\mathrm{SCAFI}) \equiv\left(\frac{\sum_{\mathrm{i}=1}^{\mathrm{m}}\left(\mathrm{x}_{\mathrm{i}} \times \mathrm{d}_{\mathrm{i}}\right)}{\sum_{\mathrm{i}=1}^{\mathrm{m}} \mathrm{x}_{\mathrm{i}}}, \frac{\sum_{\mathrm{i}=1}^{\mathrm{m}}\left(\mathrm{y}_{\mathrm{i}} \times \mathrm{e}_{\mathrm{i}}\right)}{\sum_{\mathrm{i}=1}^{\mathrm{m}} \mathrm{y}_{\mathrm{i}}}, \frac{\sum_{\mathrm{i}=1}^{\mathrm{m}}\left(\mathrm{z}_{\mathrm{i}} \times \mathrm{f}_{\mathrm{i}}\right)}{\sum_{\mathrm{i}=1}^{\mathrm{m}} \mathrm{z}_{\mathrm{i}}}\right) \equiv(\mathrm{g}, \mathrm{h}, \mathrm{k})$

Thus, the supply chain agility fuzzy index pertaining to the case organization is identified using Equation (5) as follows:

$$
\begin{gathered}
\text { SCAI }=\left(\begin{array}{c}
\frac{(0.44 \times 0.49)+(0.56 \times 0.55)+(0.50 \times 0.52)+(0.58 \times 0.52)+(0.44 \times 0.57)+(0.50 \times 0.58)}{0.44+0.56+0.50+0.58+0.44+0.50}, \\
\frac{(0.60 \times 0.64)+(0.70 \times 0.69)+(0.65 \times 0.56)+(0.72 \times 0.66)+(0.60 \times 0.71)+(0.65 \times 0.71)}{0.60+0.70+0.65+0.72+0.60+0.65}, \\
\frac{(0.76 \times 0.78)+(0.83 \times 0.82)+(0.80 \times 0.85)+(0.84 \times 0.81)+(0.74 \times 0.84)+(0.80 \times 0.84)}{0.76+0.83+0.80+0.84+0.74+0.80}
\end{array}\right) \\
\text { SCAFI }=(0.54,0.68,0.82)
\end{gathered}
$$

Phase III: Estimate the agility level of sustainable supply-chain for the purpose of picking out major barriers to enable decision makers to respond effectively and implement corrective measures (Steps 6 and 7).

Step 6: Matching SCAFI with the Linguistic Terminology to Estimate the Overall Agility-Level

Once SCAFI is computed (refer above Step 5), to estimate supply chain agility level (SCAL), the matching of SCAFI with linguistic terms is done using numerous approaches; for example, Euclidean distance [14,86], successive approximation [87], and piecewise decomposition $[87,88]$. Several recommendations referred to utilize the Euclidean distance method because it is the most intuitive and easiest method when compared to others for humans to use in perceiving proximity $[14,81]$. The Euclidean distance method is used to calculate the Euclidean distance from a given fuzzy number to each of fuzzy numbers representing the expression set of natural-language agility level. The Euclidean distance D between SCAFI and SCAL is computed as below (refer to Equation (6)) [13,85]:

$$
\begin{gathered}
\mathrm{D}\left(\mathrm{SCAFI}, \mathrm{SCAL}_{\mathrm{t}}\right)=\left\{\sum_{\mathrm{u} \in \mathrm{p}}\left[\mathrm{f}_{\mathrm{SCAFI}}(\mathrm{u})-\mathrm{f}_{\mathrm{AL}}(\mathrm{u})\right]^{2}\right\}^{\frac{1}{2}} \\
\equiv \mathrm{D}\left[(\mathrm{g}, \mathrm{h}, \mathrm{k}),\left(\mathrm{o}_{\mathrm{t}}, \mathrm{q}_{\mathrm{t}}, \mathrm{s}_{\mathrm{t}}\right)\right]=\left\{\left(\mathrm{g}-\mathrm{o}_{\mathrm{t}}\right)^{2}+\left(\mathrm{h}-\mathrm{q}_{\mathrm{t}}\right)^{2}+\left(\mathrm{k}-\mathrm{s}_{\mathrm{t}}\right)^{2}\right\}^{\frac{1}{2}}
\end{gathered}
$$

In above Equation $(6),\left(\mathrm{o}_{\mathrm{t}}, \mathrm{q}_{\mathrm{t}}, \mathrm{s}_{\mathrm{t}}\right)$ is the corresponding fuzzy set for given agility level linguistic terms (or members) for each $t \in 1$ to 5 .

The smallest Euclidean distance between SCAFI and SCAL is identified among five calculated distances (refer Equation (6)). As an example, using SCAFI $[\approx(\mathrm{g}, \mathrm{h}$, $\mathrm{k}) \approx(0.54,0.68,0.82)$ ] and $\mathrm{SCAL}_{\mathrm{t}}=1$ [agility level as 'extremely agile' $\approx\left(\mathrm{o}_{1}, \mathrm{q}_{1}, \mathrm{~s}_{1}\right) \approx$ 
$(0.70,0.85,1.00)]$ for the case organization, using Equation (6) the Euclidean distance (D) is calculated for $\mathrm{t}=1$ as follows:

$$
\begin{aligned}
\mathrm{D}\left(\mathrm{SCAFI}, \mathrm{SCAL}_{\mathrm{t}=1}\right)= & \left\{(0.54-0.70)^{2}+(0.68-0.85)^{2}+(0.82-1.00)^{2}\right\}^{\frac{1}{2}} \\
& \mathrm{D}\left(\mathrm{SCAFI}, \mathrm{SCAL}_{\mathrm{t}=1}\right)=0.30
\end{aligned}
$$

Similarly, other Euclidean distances for given agility level linguistic terms (or members) for each $t \in 1$ to 5 are computed and presented here below in matrix form.

$\mathrm{D}\left(\mathrm{SCAFI}, \mathrm{SCAL} L_{\mathrm{t}}\right)=$ Least of $\left\{\begin{array}{ccc}\text { agility level } \downarrow & \mathrm{t} \downarrow & \mathrm{D} \downarrow \\ \text { extreamly agile } & 1 & 0.30 \\ \text { very agile } & 2 & 0.04 \\ \text { agile } & 3 & 0.31 \\ \text { fairly agile } & 4 & 0.65 \\ \text { slowly agile } & 5 & 0.91\end{array}\right\}$

$=[\mathrm{D}$ minimum is 0.04 , so corresponding $\mathrm{t}$ is 2 , it means very agile is overall agility level $]$

Therefore, as a result of matching a linguistic agility level with the minimum $\mathrm{D}$, the supply chain agility level for the case organization is evaluated as "very agile."

Step 7: Identify Barriers to Improve Sustainable Supply Chain Agility-Level

After defining SCAL of the case organization, it is set to identify the barriers to achieve the next level of agility, a fuzzy performance index (FPI) is computed by combining computed rates and weights for supply chain enablers and attributes that influence agility level. With dropping of FPI, the contribution degree for a factor of agile supply drops. Therefore, the fuzzy performance index (FPI) defines the main barriers of agile supply chain, and is computed using Equation (7) [13,14,16,67]:

$$
\mathrm{FPI}_{\mathrm{j}}=\left\{\left[1-\mathrm{W}_{\mathrm{j}}\right] \times \mathrm{R}_{\mathrm{j}}\right\}_{\mathrm{i}} \equiv\left(\mathrm{A}_{\mathrm{j}}, \mathrm{B}_{\mathrm{j}}, \mathrm{C}_{\mathrm{j}}\right)_{\mathrm{i}}=\left(\left[1-\mathrm{x}_{\mathrm{j}}\right] \times \mathrm{a}_{\mathrm{j}},\left[1-\mathrm{y}_{\mathrm{j}}\right] \times \mathrm{b}_{\mathrm{j}},\left[1-\mathrm{z}_{\mathrm{j}}\right] \times \mathrm{c}_{\mathrm{j}}\right)_{\mathrm{i}}
$$

In Equation (7), for the given $i$ and $j, F_{j} \approx\left(A_{j}, B_{j}, C_{j}\right)_{i}$ is fuzzy performance importance index, $R_{j} \approx\left(a_{j}, b_{j}, c_{j}\right)_{i}$ is fuzzy ratings, and $W_{j} \approx\left(x_{j}, y_{j}, z_{j}\right)_{i}$ is fuzzy weights. As computation of fuzzy performance importance index results always the non-orderly set of real fuzzy numbers, the left-and-right fuzzy-ranking method has been adopted to rank fuzzy numbers $[73,89,90]$. The drawback of the approach is that for diverse fuzzy set numbers, the ranking score will be different [91]. The range, i.e., maximum and minimum fuzzy sets numbers are set using below Equations (8) and (9).

$$
\begin{aligned}
& \mathrm{U}_{\max (\mathrm{x})}=\left\{\begin{array}{ll}
\mathrm{x}, & 0 \leq \mathrm{x} \leq 1, \\
0, & \text { otherwise }
\end{array}\right\}, \\
& \mathrm{U}_{\min (\mathrm{x})}=\left\{\begin{array}{ll}
1-\mathrm{x}, & 0 \leq \mathrm{x} \leq 1, \\
0, & \text { otherwise }
\end{array}\right\}
\end{aligned}
$$

Thus, the left-and-right fuzzy-ranking scores is computed (refer below Equations (10) and (11)) by using $\sup _{\mathrm{x}}\left[\mathrm{U}_{\mathrm{FPI}_{\mathrm{ij}}}(\mathrm{x}) \mathrm{U}_{\max (\mathrm{x})}\right]$ : the ordinate of the intersecting point of $\mathrm{U}_{\max }$ and right leg of $\mathrm{U}_{\mathrm{FPI}_{\mathrm{ij}}}$; and $\sup _{\mathrm{x}}\left[\mathrm{U}_{\mathrm{FPI}_{\mathrm{ij}}}(\mathrm{x}) \mathrm{U}_{\min (\mathrm{x})}\right]$ : the ordinate of the intersecting point of $\mathrm{U}_{\text {min }}$ and left leg of $\mathrm{U}_{\mathrm{FPI}_{\mathrm{ij}}}[13,92]$. And, lastly FPI total score is computed by combining the left and right scores (refer below Equation (12)).

$$
\begin{aligned}
& \mathrm{U}_{\mathrm{R}}\left(\mathrm{FPI}_{\mathrm{ij}}\right)=\sup _{\mathrm{x}}\left[\mathrm{U}_{\mathrm{FPI}_{\mathrm{ij}}}(\mathrm{x}) \mathrm{U}_{\max (\mathrm{x})}\right]=\frac{\mathrm{C}_{\mathrm{ij}}}{1+\mathrm{C}_{\mathrm{ij}}-\mathrm{B}_{\mathrm{ij}}} \\
& \mathrm{U}_{\mathrm{L}}\left(\mathrm{FPI}_{\mathrm{ij}}\right)=\sup _{\mathrm{x}}\left[\mathrm{U}_{\mathrm{FPI}_{\mathrm{ij}}}(\mathrm{x}) \mathrm{U}_{\min (\mathrm{x})}\right]=\frac{1-\mathrm{A}_{\mathrm{ij}}}{1+\mathrm{B}_{\mathrm{ij}}-\mathrm{A}_{\mathrm{ij}}}
\end{aligned}
$$




$$
\mathrm{U}_{\mathrm{T}}\left(\mathrm{FPI}_{\mathrm{ij}}\right)=\frac{\mathrm{U}_{\mathrm{R}}\left(\mathrm{FPI}_{\mathrm{ij}}\right)+1-\mathrm{U}_{\mathrm{L}}\left(\mathrm{FPI}_{\mathrm{ij}}\right)}{2}
$$

For the case organization, the supply chain agility level is "VA: very-agile"; it is still far from "EA: extremely agile." This is because of different barriers to improving within the organization supply chain that restricted the agility level. These agility barriers can be defined by obtaining FPI using above Equation (7). FPI calculation sample of the agile supply chain attribute "Material planning" $(i=1, j=1)$ is as follows:

$$
\begin{gathered}
\mathrm{FPI}_{11}=[1-(0.52,0.67,0.81)] \times(0.47,0.62,0.76) \\
\mathrm{FPI}_{11}=([1-0.81] \times 0.47,[1-0.67] \times 0.62,[1-0.52] \times 0.76) \\
\operatorname{FPI}_{11}=(0.09,0.21,0.36)
\end{gathered}
$$

Similarly, FPI of all 93 agile supply chain attributes are calculated, as listed in Table 6. As computation of fuzzy performance importance index resulted into the non-orderly set of real fuzzy numbers, Equations (8)-(12) were used to defuzzify FPIs. As a sample, the

\begin{tabular}{|c|c|c|c|c|c|c|}
\hline Sustainable Enablers (i) & $\mathbf{j}$ & $\begin{array}{c}\text { Sustainable } \\
\text { Attributes } \text { FPI }_{\mathbf{i j}}\end{array}$ & Ranking Score & $\mathbf{j}$ & $\begin{array}{c}\text { Sustainable } \\
\text { Attributes } \text { FPI }_{\mathbf{i j}}\end{array}$ & Ranking Score \\
\hline & 1 & $(0.09,0.21,0.36)$ & 0.25 & 11 & $(0.12,0.25,0.41)$ & 0.29 \\
\hline & 2 & $(0.08,0.19,0.36)$ & 0.24 & 12 & $(0.14,0.28,0.46)$ & 0.32 \\
\hline & 3 & $(0.08,0.20,0.37)$ & 0.25 & 13 & $(0.09,0.20,0.37)$ & 0.25 \\
\hline & 4 & $(0.09,0.20,0.36)$ & 0.25 & 14 & $(0.10,0.23,0.41)$ & 0.27 \\
\hline 1: Organization & 5 & $(0.08,0.19,0.35)$ & 0.24 & 15 & $(0.12,0.27,0.48)$ & 0.32 \\
\hline \multirow[t]{13}{*}{ Management } & 6 & $(0.12,0.26,0.46)$ & 0.31 & 16 & $(0.15,0.30,0.48)$ & 0.33 \\
\hline & 7 & $(0.13,0.28,0.46)$ & 0.32 & 17 & $(0.08,0.19,0.34)$ & 0.23 \\
\hline & 8 & $(0.10,0.21,0.36)$ & 0.25 & 18 & $(0.09,0.22,0.39)$ & 0.26 \\
\hline & 9 & $(0.10,0.22,0.38)$ & 0.26 & 19 & $(0.09,0.20,0.35)$ & 0.24 \\
\hline & 10 & $(0.14,0.27,0.44)$ & 0.31 & 20 & $(0.07,0.18,0.33)$ & 0.22 \\
\hline & 1 & $(0.10,0.23,0.41)$ & 0.28 & 18 & $(0.12,0.24,0.41)$ & 0.28 \\
\hline & 2 & $(0.17,0.32,0.52)$ & 0.35 & 19 & $(0.11,0.24,0.39)$ & 0.27 \\
\hline & 3 & $(0.11,0.22,0.37)$ & 0.26 & 20 & $(0.09,0.20,0.34)$ & 0.24 \\
\hline & 4 & $(0.13,0.28,0.47)$ & 0.32 & 21 & $(0.13,0.23,0.38)$ & 0.27 \\
\hline & 5 & $(0.13,0.24,0.38)$ & 0.27 & 22 & $(0.09,0.21,0.36)$ & 0.25 \\
\hline & 6 & $(0.10,0.22,0.37)$ & 0.26 & 23 & $(0.10,0.22,0.40)$ & 0.27 \\
\hline & 7 & $(0.13,0.28,0.46)$ & 0.32 & 24 & $(0.13,0.26,0.42)$ & 0.29 \\
\hline & 8 & $(0.11,0.23,0.40)$ & 0.27 & 25 & $(0.15,0.27,0.42)$ & 0.30 \\
\hline \multirow[t]{9}{*}{ 2: Strategic Management } & 9 & $(0.16,0.31,0.48)$ & 0.34 & 26 & $(0.11,0.21,0.33)$ & 0.24 \\
\hline & 10 & $(0.09,0.21,0.37)$ & 0.25 & 27 & $(0.12,0.26,0.45)$ & 0.30 \\
\hline & 11 & $(0.08,0.19,0.35)$ & 0.24 & 28 & $(0.14,0.29,0.46)$ & 0.32 \\
\hline & 12 & $(0.13,0.25,0.40)$ & 0.28 & 29 & $(0.09,0.22,0.40)$ & 0.27 \\
\hline & 13 & $(0.11,0.23,0.38)$ & 0.27 & 30 & $(0.10,0.20,0.33)$ & 0.24 \\
\hline & 14 & $(0.15,0.27,0.42)$ & 0.30 & 31 & $(0.11,0.22,0.37)$ & 0.26 \\
\hline & 15 & $(0.14,0.29,0.49)$ & 0.33 & 32 & $(0.10,0.22,0.38)$ & 0.26 \\
\hline & 16 & $(0.14,0.28,0.44)$ & 0.31 & 33 & $(0.12,0.25,0.41)$ & 0.29 \\
\hline & 17 & $(0.14,0.26,0.43)$ & 0.30 & 34 & $(0.18,0.33,0.51)$ & 0.36 \\
\hline
\end{tabular}
ranking score of the attribute "material planning" $(i=1, j=1)$ is as follows:

$$
\mathrm{U}_{\mathrm{R}}\left(\mathrm{FPI}_{11}\right)=\frac{0.36}{1+0.36-0.21}=0.31 \quad \mathrm{U}_{\mathrm{L}}\left(\mathrm{FPI}_{11}\right)=\frac{1-0.09}{1+0.21-0.09}=0.82 \quad \mathrm{U}_{\mathrm{T}}\left(\mathrm{FPI}_{11}\right)=\frac{[0.31+1-0.82]}{2}=0.25
$$

Table 6. Fuzzy merit-importance indices (FPI) of sustainable attributes. 
Table 6. Cont.

\begin{tabular}{|c|c|c|c|c|c|c|}
\hline Sustainable Enablers (i) & $\mathbf{j}$ & $\begin{array}{c}\text { Sustainable } \\
\text { Attributes } \text { FPI }_{\mathrm{ij}}\end{array}$ & Ranking Score & $\mathbf{j}$ & $\begin{array}{c}\text { Sustainable } \\
\text { Attributes FPI }{ }_{i j}\end{array}$ & Ranking Score \\
\hline \multirow{6}{*}{ 3: Strategic Commitment } & 1 & $(0.09,0.20,0.36)$ & 0.24 & 7 & $(0.11,0.24,0.40)$ & 0.28 \\
\hline & 2 & $(0.09,0.22,0.39)$ & 0.26 & 8 & $(0.12,0.25,0.43)$ & 0.29 \\
\hline & 3 & $(0.08,0.20,0.35)$ & 0.24 & 9 & $(0.09,0.22,0.38)$ & 0.26 \\
\hline & 4 & $(0.12,0.25,0.42)$ & 0.29 & 10 & $(0.09,0.21,0.36)$ & 0.25 \\
\hline & 5 & $(0.10,0.22,0.39)$ & 0.27 & 11 & $(0.12,0.26,0.45)$ & 0.30 \\
\hline & 6 & $(0.08,0.19,0.34)$ & 0.23 & 12 & $(0.13,0.29,0.49)$ & 0.33 \\
\hline \multirow{5}{*}{$\begin{array}{l}\text { 4: Information } \\
\text { Management }\end{array}$} & 1 & $(0.12,0.24,0.39)$ & 0.28 & 6 & $(0.10,0.20,0.34)$ & 0.24 \\
\hline & 2 & $(0.14,0.26,0.42)$ & 0.30 & 7 & $(0.08,0.19,0.35)$ & 0.24 \\
\hline & 3 & $(0.12,0.26,0.43)$ & 0.30 & 8 & $(0.13,0.25,0.41)$ & 0.29 \\
\hline & 4 & $(0.06,0.17,0.32)$ & 0.21 & 9 & $(0.09,0.21,0.38)$ & 0.26 \\
\hline & 5 & $(0.14,0.26,0.43)$ & 0.30 & 10 & $(0.08,0.19,0.34)$ & 0.23 \\
\hline \multirow{4}{*}{ 5: Customer Sensitivity } & 1 & $(0.10,0.22,0.39)$ & 0.27 & 5 & $(0.11,0.23,0.39)$ & 0.27 \\
\hline & 2 & $(0.13,0.26,0.44)$ & 0.30 & 6 & $(0.11,0.23,0.38)$ & 0.26 \\
\hline & 3 & $(0.13,0.25,0.41)$ & 0.29 & 7 & $(0.08,0.19,0.35)$ & 0.24 \\
\hline & 4 & $(0.09,0.21,0.36)$ & 0.25 & 8 & $(0.07,0.17,0.32)$ & 0.22 \\
\hline \multirow{5}{*}{ 6: Human Competence } & 1 & $(0.11,0.23,0.39)$ & 0.27 & 6 & $(0.10,0.23,0.40)$ & 0.27 \\
\hline & 2 & $(0.13,0.28,0.46)$ & 0.32 & 7 & $(0.12,0.26,0.44)$ & 0.30 \\
\hline & 3 & $(0.14,0.28,0.46)$ & 0.32 & 8 & $(0.10,0.22,0.38)$ & 0.26 \\
\hline & 4 & $(0.16,0.31,0.49)$ & 0.34 & 9 & $(0.10,0.22,0.38)$ & 0.26 \\
\hline & 5 & $(0.10,0.22,0.38)$ & 0.26 & & & \\
\hline
\end{tabular}

Similarly, a ranking of all other agile supply chain attributes have been calculated, as listed in the Table 6.

To determine supply chain agility barriers, it is important to set a threshold value. Attributes with ranking scores less than the threshold value are barriers to supply-chain agility. Thus, based on Pareto-principle [86,87], threshold-value in this study for the case organization is set to 0.24829 . Table 6 indicates that 21 attributes performed below the threshold value. These 21 agile supply chain attributes are called agility barriers, as shown in Table 7.

Table 7. Shortlisted sustainable attributes acting as barriers for each sustainable enabler.

\begin{tabular}{ccc}
\hline Sustainable Enablers & $\begin{array}{c}\text { Sustainable Barriers Based on Least } \\
\text { Ranking Score }\end{array}$ & Ranking-Score \\
\hline \multirow{2}{*}{ Organization Management } & Demand of supply planning & 0.22 \\
& Manufacturing capabilities & 0.23 \\
& Integrated logistic networks & 0.24 \\
& Organizational structure & 0.24 \\
& Cooperating with companies & 0.24 \\
& Virtual logistics networks & 0.25 \\
\hline Strategic Management & Rapid decision making & 0.24 \\
& Excellent communication & 0.24 \\
& Effective utilization of time & 0.24 \\
& Time compression technologies & 0.24 \\
& Effective serviceability & 0.25 \\
\hline Strategic Commitment & Associate trust and competence & 0.23 \\
& Selection of suppliers & 0.24 \\
& Interlinking departments & 0.24 \\
& Integration of core competencies & 0.25 \\
\hline
\end{tabular}


Table 7. Cont.

\begin{tabular}{ccc}
\hline Sustainable Enablers & $\begin{array}{c}\text { Sustainable Barriers Based on Least } \\
\text { Ranking Score }\end{array}$ & Ranking-Score \\
\hline \multirow{3}{*}{ Information Management } & Digitization of partners' feedback & 0.21 \\
& Early disturbances detection & 0.23 \\
& World Wide Web & 0.24 \\
\multirow{2}{*}{ Customer/Marketing Sensitivity } & Incorporating RFID technology & 0.24 \\
\hline & Universalization of customers & 0.22 \\
& Effective forecasting method & 0.24 \\
\hline
\end{tabular}

The attributes listed in the above Table 7 are the most important contributions allowing the case organization supply chain for improving agility. Therefore, an action plan would be implemented to enhance these barriers and improve the overall agile supply chain of the organization. The main findings and implications of the study for the case organization are discussed in the following section.

\section{Managerial Discussion and Its Implications}

The organization stakeholders and mangers as decision makers are bound to try or to establish best practices across their entire supply chain through combined efforts working towards overcoming barriers to achieve sustainable agile supply chain. For the case study on hand, their supply chain has been subject to criticism due to their lack of desired focus on supply chain strategies in context to local and global market. It is evident that a majority of the existing literature on agility assessment is being dominated by theoretical and empirical studies and conceptual models. Thus, it is projected to develop a step-by-step approach for the assessment of supply chain agility and further in result to shortlist the desired agility enablers and barriers to propel towards the desired organizational goal.

The management of the case organization set the objectives to overcome with unexpected challenges, and propelling to survive with unexpected threats of business environment. They desired to estimate their current agility to provide customer-driven products and services in a complex and dynamic interactive market, logistics, and distribution system. There is also desire to explore competitive base and sustainable strategies to be successful in a changing market environment. The presented approach is adopted by the management to increase understanding of the behaviour of their supply chain.

The approach also supported them to develop a strategic solution for their specific organizational agility barriers. Here in the presented case study, the stakeholders and managers as decision makers have realized that agility in their sustainable supply chain is quite essential for the survival and competitiveness. In the way of implementing agility in the sustainable supply chain, the issues to be examined were discussed about agility, its measurement, agility level, and barriers. The assessment of agility in supply chains is termed by managers as an indicator and evaluation of the strategic agile position of their supply chain in the present and future competitive business environment. Stakeholders set freehand to explore managerial practice having a knowledge-rich environment and integration of resources. The presented approach is widely acceptable by the organizational decisions makers, since it assisted the managers in better achieving and easy to measure organization' agility of supply chain. The framework presented is systematic and comprehensive of multiple factors that contribute to achieving sustainable supply chain agility.

From the computation of agility indices for each sustainable enabler, the decision makers are suggested to focus in order of priority on organization management, followed by both information management and strategic commitments, and then to strategic management, lastly least importance to both customer sensitivity and human competence in their supply chain.

Organization management is an agility sustainable enabler factor in dealing with material handling, layout, equipment, processes, plant, etc. Market-oriented financial goals, 
return on assets, market share, and growth rate all contribute to enhancing organizational and supply chain productivity. Strategic management is an agility enabler contributing to the goal of the strategic alliances among supply chain partners, which is to obtain cost and quality advantages as well as to guarantee the smooth flow of operations. The strategies related to business management, inventory, time management, production and quality, and product design and service contribute to enhance supply chain agility. Strategic commitment is a factor to enhance and encourage eco-innovation to proactively update the manufacturing processes and production schedule within supply chain partners. Information management refers to sharing of agile practices, sharing of information architecture and tradable competencies, final product information, and partners' feedback among the supply chain participants. Customer sensitivity and human competence are factors determining the agility of a supply chain. These factors refer to practices used by an organization to enhance their relationship with customers to serve their needs in a timely and cost-efficient manner by employees through continuous improvement-focused approaches. This is achieved by understanding, analysing, and managing customer expectations, and effectively and efficiently dealing with complaints. This is determined by the employees within the organization, who are assessed based on training and motivation.

\section{Conclusions}

The proposed approach is efficient to rank sustainable enablers and attributes for evaluating supply chain agility, and is also capable of handling multiple quantitative and qualitative attributes, but there are some limitations. In this context, from the results of the fuzzy assessment of sustainable supply chain agility for the case organization, it is evident that the manufacturing organization supply chain is very agile. There are twenty-one barriers (refer the above Table 7) out of the total ninety-three attributes (refer above Table 2) within their supply chain that impact the agility-level. Within selected agility barriers, the case organization should have foremost priority on strategies to enhance maintainability and serviceability to make it flexible and inexpensive to establish agile responsive supply chain. At the same time, it should have priority to focus on development and integration of their core competencies to deal with cross-functional and cross-enterprise issues in supply chain. While, in response to an uncertain, comparative, and dynamic global market, and having focus on flexibility and agility, the least preference would be given to demandsupply planning, supply-chain partners' feedback, as well as universalization of market or customer. The limitations and recommendations for other researchers are concluded here below.

Limitations of the assessment approach depends on the managerial perspective of the experts, who are associated in the organization to evaluate the importance of all aspects such as strategy, marketing, and technology. Furthermore, identification of agility capabilities, enablers, and attributes vary from one organization or industry to another; these should be appropriate to organization's own specific environment and considerations. In addition, the computation of weights, overall agility level, or index are complicated and not easily appreciated by managers. So, these calculations can be computerized to increase accuracy while reducing both computation time and the possibility of errors.

Similarly, supply chain agility assessment was carried out in a single manufacturing organization. However, a number of local case studies could be conducted in future for varied organizations across manufacturing and service sectors to improve the validity of the presented approach in future. Thus, improvement based on the use hybrid decision making approach to assess sustainable supply chain agility can be one solution to overcome on limitations.

Lastly, supply chain sustainability aspects related to economic and business performance that can be deployed in future research, are planned as:

- Develop the model to assess the relationship between agility factors and their impact on financial performance of the sustainable supply chain network. 
- Developing an approach that integrates capabilities, enablers, and attributes to design a dynamic supply chain system by incorporating information technology and networks investments and a multi-functional workforce to study the impact of supply chain agility and adaptability on corporate performance.

- Developing a software that carries out the computations required to assess a sustainable supply chain to make it easy to provide online real time shortlisting of agility barriers and highlight their implications based on past experiences.

- Conducting in-depth studies of several market segments such as automotive, electronics, pharmaceutical, entertainment, etc. as well as service, retail, and construction sectors to formulate more precise and focused different models and approaches for the assessment of supply chain.

Author Contributions: Conceptualization, A.U.R., M.A., and A.A.-Z.; methodology, A.U.R., M.A., and A.A.-Z.; formal analysis, A.U.R., M.A., and A.A.-Z.; investigation, A.U.R. and A.A.-Z.; writingoriginal draft preparation, A.U.R. and A.A.-Z.; writing-review and editing, A.U.R., M.A., and A.A.-Z.; supervision, A.U.R. and M.A.; funding acquisition, M.A. and A.U.R. All authors have read and agreed to the published version of the manuscript.

Funding: This research was funded by the Raytheon Chair for Systems Engineering.

Institutional Review Board Statement: Not applicable.

Informed Consent Statement: Not applicable.

Data Availability Statement: Data is available here within the paper.

Acknowledgments: The authors are grateful to the Raytheon Chair for Systems Engineering for funding.

Conflicts of Interest: The authors declare no conflict of interest.

\section{References}

1. Gunasekaran, A.; Tirtiroglu, E.; Wolstencroft, V. An Investigation into the Application of Agile Manufacturing in an Aerospace Company. Technovation 2002, 22, 405-415. [CrossRef]

2. Heizer, J.H.; Render, B. Operations Management; Pearson Education: London, UK, 2011; ISBN 978-0-13-511143-7.

3. Munteanu, A.-I.; Bibu, N.; Nastase, M.; Cristache, N.; Matis, C. Analysis of Practices to Increase the Workforce Agility and to Develop a Sustainable and Competitive Business. Sustainability 2020, 12, 3545. [CrossRef]

4. Ismail, H.S.; Sharifi, H. A Balanced Approach to Building Agile Supply Chains. Int. J. Phys. Distrib. Logist. Manag. 2006, 36, 431-444. [CrossRef]

5. Dwayne Whitten, G.; Green, K.W.; Zelbst, P.J. Triple-A Supply Chain Performance. Int. J. Oper. Prod. Manag. 2012, 32, 28-48. [CrossRef]

6. Breu, K.; Hemingway, C.J.; Strathern, M.; Bridger, D. Workforce Agility: The New Employee Strategy for the Knowledge Economy. J. Inf. Technol. 2002, 17, 21-31. [CrossRef]

7. Yusuf, Y.Y.; Gunasekaran, A.; Adeleye, E.O.; Sivayoganathan, K. Agile Supply Chain Capabilities: Determinants of Competitive Objectives. Eur. J. Oper. Res. 2004, 159, 379-392. [CrossRef]

8. Van Hoek, R.I.; Harrison, A.; Christopher, M. Measuring Agile Capabilities in the Supply Chain. Int. J. Oper. Prod. Manag. 2001, 21, 126-148. [CrossRef]

9. Jain, V.; Benyoucef, L.; Deshmukh, S.G. A New Approach for Evaluating Agility in Supply Chains Using Fuzzy Association Rules Mining. Eng. Appl. Artif. Intell. 2008, 21,367-385. [CrossRef]

10. Youssef, M.A. The Impact of the Intensity Level of Computer-based Technologies on Quality. Int. J. Oper. Prod. Manag. 1994, 14, 4-25. [CrossRef]

11. Christopher, M. The Agile Supply Chain: Competing in Volatile Markets. Ind. Mark. Manag. 2000, 29, 37-44. [CrossRef]

12. Swafford, P.M.; Ghosh, S.; Murthy, N. Achieving Supply Chain Agility through IT Integration and Flexibility. Int. J. Prod. Econ. 2008, 116, 288-297. [CrossRef]

13. Singh Patel, B.; Samuel, C.; Sharma, S.K. Evaluation of Agility in Supply Chains: A Case Study of an Indian Manufacturing Organization. J. Manuf. Technol. Manag. 2017, 28, 212-231. [CrossRef]

14. Vinodh, S.; Devadasan, S.R.; Vimal, K.E.K.; Kumar, D. Design of Agile Supply Chain Assessment Model and Its Case Study in an Indian Automotive Components Manufacturing Organization. J. Manuf. Syst. 2013, 32, 620-631. [CrossRef]

15. Mishra, S.; Samantra, C.; Datta, S.; Mahapatra, S.S. Agility Appraisement Framework for Integrated Supply Chain Using Generalised Interval-Valued Fuzzy Set. Int. J. Bus. Inf. Syst. 2014, 16, 89-118. [CrossRef]

16. Lin, C.-T.; Chiu, H.; Chu, P.-Y. Agility Index in the Supply Chain. Int. J. Prod. Econ. 2006, 100, 285-299. [CrossRef] 
17. Gligor, D.M.; Holcomb, M. The Road to Supply Chain Agility: An RBV Perspective on the Role of Logistics Capabilities. Int. J. Logist. Manag. 2014, 25, 160-179. [CrossRef]

18. Gunasekaran, A.; Patel, C.; Tirtiroglu, E. Performance Measures and Metrics in a Supply Chain Environment. Int. J. Oper. Prod. Manag. 2001, 21, 71-87. [CrossRef]

19. Vinodh, S.; Prasanna, M. Evaluation of Agility in Supply Chains Using Multi-Grade Fuzzy Approach. Int. J. Prod. Res. 2011, 49, 5263-5276. [CrossRef]

20. Sangari, M.S.; Razmi, J.; Zolfaghari, S. Developing a Practical Evaluation Framework for Identifying Critical Factors to Achieve Supply Chain Agility. Measurement 2015, 62, 205-214. [CrossRef]

21. Jain, V.; Benyoucef, L.; Deshmukh, S.G. What's the Buzz about Moving from 'Lean' to 'Agile' Integrated Supply Chains? A Fuzzy Intelligent Agent-Based Approach. Int. J. Prod. Res. 2008, 46, 6649-6677. [CrossRef]

22. Gligor, D.M.; Esmark, C.L.; Holcomb, M.C. Performance Outcomes of Supply Chain Agility: When Should You Be Agile? J. Oper. Manag. 2015, 33-34, 71-82. [CrossRef]

23. Ganguly, A.; Nilchiani, R.; Farr, J.V. Evaluating Agility in Corporate Enterprises. Int. J. Prod. Econ. 2009, 118, 410-423. [CrossRef]

24. Wu, K.-J.; Tseng, M.-L.; Chiu, A.S.F.; Lim, M.K. Achieving Competitive Advantage through Supply Chain Agility under Uncertainty: A Novel Multi-Criteria Decision-Making Structure. Int. J. Prod. Econ. 2017, 190, 96-107. [CrossRef]

25. Tsourveloudis, N.C.; Valavanis, K.P. On the Measurement of Enterprise Agility. J. Intell. Robot. Syst. 2002, 33, 329-342. [CrossRef]

26. Bottani, E. A Fuzzy QFD Approach to Achieve Agility. Int. J. Prod. Econ. 2009, 119, 380-391. [CrossRef]

27. AlKahtani, M.; Rehman, A.U.; Al-Zabidi, A.; Choudhary, A. Agile Supply Chain Assessment: An Empirical Study on Concepts, Research and Issues. Arab. J. Sci. Eng. 2019, 44, 2551-2565. [CrossRef]

28. Geyi, D.G.; Yusuf, Y.; Menhat, M.S.; Abubakar, T.; Ogbuke, N.J. Agile Capabilities as Necessary Conditions for Maximising Sustainable Supply Chain Performance: An Empirical Investigation. Int. J. Prod. Econ. 2020, 222, 107501. [CrossRef]

29. Swafford, P.M.; Ghosh, S.; Murthy, N. The Antecedents of Supply Chain Agility of a Firm: Scale Development and Model Testing. J. Oper. Manag. 2006, 24, 170-188. [CrossRef]

30. Soni, G.; Kodali, R. Evaluating Reliability and Validity of Lean, Agile and Leagile Supply Chain Constructs in Indian Manufacturing Industry. Prod. Plan. Control 2012, 23, 864-884. [CrossRef]

31. Azevedo, S.G.; Govindan, K.; Carvalho, H.; Cruz-Machado, V. An Integrated Model to Assess the Leanness and Agility of the Automotive Industry. Resour. Conserv. Recycl. 2012, 66, 85-94. [CrossRef]

32. Blome, C.; Schoenherr, T.; Rexhausen, D. Antecedents and Enablers of Supply Chain Agility and Its Effect on Performance: A Dynamic Capabilities Perspective. Int. J. Prod. Res. 2013, 51, 1295-1318. [CrossRef]

33. Yusuf, Y.Y.; Gunasekaran, A.; Musa, A.; Dauda, M.; El-Berishy, N.M.; Cang, S. A Relational Study of Supply Chain Agility, Competitiveness and Business Performance in the Oil and Gas Industry. Int. J. Prod. Econ. 2014, 147, 531-543. [CrossRef]

34. Balaji, M.; Velmurugan, V.; Subashree, C.; Balaji, M.; Velmurugan, V.; Subashree, C. TADS: An Assessment Methodology for Agile Supply Chains. J. Appl. Res. Technol. 2015, 13, 504-509. [CrossRef]

35. Chen, Z. Agility Indexes and Application of Production Planning. Chin. J. Mech. Eng. 2006, 19, 352-355. [CrossRef]

36. Elmoselhy, S.A.M. Hybrid Lean-Agile Manufacturing System Technical Facet, in Automotive Sector. J. Manuf. Syst. 2013, 32, 598-619. [CrossRef]

37. Faisal, M.N.; Banwet, D.K.; Shankar, R. An Approach to Measure Supply Chain Agility. Int. J. Ind. Syst. Eng. 2006, 2, 79-98. [CrossRef]

38. Kisperska-Moron, D.; Swierczek, A. The Agile Capabilities of Polish Companies in the Supply Chain: An Empirical Study. Int. J. Prod. Econ. 2009, 118, 217-224. [CrossRef]

39. Sreenivasa, C.G.; Devadasan, S.R.; Murugesh, R. Enhancing Total Agility Level through Assessment and Product Mapping: A Case Study in the Manufacturing of Refrigeration Air Dryer. Int. J. Adv. Manuf. Technol. 2012, 60, 421-436. [CrossRef]

40. Vinodh, S.; Aravindraj, S. Agility Evaluation Using the IF-THEN Approach. Int. J. Prod. Res. 2012, 50, 7100-7109. [CrossRef]

41. Charles, A.; Lauras, M.; Van Wassenhove, L. A Model to Define and Assess the Agility of Supply Chains: Building on Humanitarian Experience. Int. J. Phys. Distrib. Logist. Manag. 2010, 40, 722-741. [CrossRef]

42. Ghatari, A.R.; Mehralian, G.; Zarenezhad, F. Developing a Model for Agile Pharmaceutical Manufacturing: Evidence from Iran. Aust. J. Basic Appl. Sci. 2012, 6, 753-762.

43. Mehralian, G.; Zarenezhad, F.; Rajabzadeh Ghatari, A. Developing a Model for an Agile Supply Chain in Pharmaceutical Industry. Int. J. Pharm. Healthc. Mark. 2015, 9, 74-91. [CrossRef]

44. Samantra, C.; Datta, S.; Mishra, S.; Mahapatra, S.S. Agility Appraisal for Integrated Supply Chain Using Generalized Trapezoidal Fuzzy Numbers Set. Int. J. Adv. Manuf. Technol. 2013, 68, 1491-1503. [CrossRef]

45. Matawale, C.R.; Datta, S.; Mahapatra, S.S. Agility Appraisement and Identification of Agile Barriers in a Supply Chain. Int. J. Serv. Oper. Manag. 2013, 16, 478-505. [CrossRef]

46. Khalili-Damghani, K.; Tavana, M. A New Fuzzy Network Data Envelopment Analysis Model for Measuring the Performance of Agility in Supply Chains. Int. J. Adv. Manuf. Technol. 2013, 69, 291-318. [CrossRef]

47. Khalili-Damghani, K.; Sadi-Nezhad, S.; Hosseinzadeh-Lotfi, F. Imprecise DEA Models to Assess the Agility of Supply Chains. In Supply Chain Management Under Fuzziness: Recent Developments and Techniques; Kahraman, C., Öztayşi, B., Eds.; Studies in Fuzziness and Soft Computing; Springer: Berlin/Heidelberg, Germany, 2014; pp. 167-198. ISBN 978-3-642-53939-8. 
48. Matawale, C.R.; Datta, S.; Mahapatra, S.S. Evaluation of Leanness, Agility and Leagility for Supply Chain of Automotive Industries. Int. J. Agil. Syst. Manag. 2015, 8, 85-115. [CrossRef]

49. Liu, W.; Xu, H.; Zhao, X. Agile Service Oriented Shipping Companies in the Container Terminal. Transport 2009, $24,143-153$. [CrossRef]

50. Trkman, P.; McCormack, K.; de Oliveira, M.P.V.; Ladeira, M.B. The Impact of Business Analytics on Supply Chain Performance. Decis. Support Syst. 2010, 49, 318-327. [CrossRef]

51. Ngai, E.W.T; Chau, D.C.K.; Chan, T.L.A. Information Technology, Operational, and Management Competencies for Supply Chain Agility: Findings from Case Studies. J. Strateg. Inf. Syst. 2011, 20, 232-249. [CrossRef]

52. Liu, H.; Ke, W.; Wei, K.K.; Hua, Z. The Impact of IT Capabilities on Firm Performance: The Mediating Roles of Absorptive Capacity and Supply Chain Agility. Decis. Support Syst. 2013, 54, 1452-1462. [CrossRef]

53. Soni, U.; Jain, V.; Kumar, S. Measuring Supply Chain Resilience Using a Deterministic Modeling Approach. Comput. Ind. Eng. 2014, 74, 11-25. [CrossRef]

54. Asad, M.M.; Mohammadi, V.; Shirani, M. Modeling Flexibility Capabilities of IT-Based Supply Chain, Using a Grey-Based DEMATEL Method. Procedia Econ. Financ. 2016, 36, 220-231. [CrossRef]

55. Liu, J.; Zhu, J.; Zhang, J. A DEA-Based Approach for Competitive Environment Analysis in Global Operations Strategies. Int. J. Prod. Econ. 2018, 203, 110-123. [CrossRef]

56. Lima-Junior, F.R.; Carpinetti, L.C.R. Predicting Supply Chain Performance Based on SCOR®Metrics and Multilayer Perceptron Neural Networks. Int. J. Prod. Econ. 2019, 212, 19-38. [CrossRef]

57. Lima-Junior, F.R.; Carpinetti, L.C.R. An Adaptive Network-Based Fuzzy Inference System to Supply Chain Performance Evaluation Based on SCOR®Metrics. Comput. Ind. Eng. 2020, 139, 106191. [CrossRef]

58. Karmaker, C.L.; Ahmed, T.; Ahmed, S.; Ali, S.M.; Moktadir, M.A.; Kabir, G. Improving Supply Chain Sustainability in the Context of COVID-19 Pandemic in an Emerging Economy: Exploring Drivers Using an Integrated Model. Sustain. Prod. Consum. 2021, 26, 411-427. [CrossRef]

59. Kumar, D.; Ramakrishna, H. Assessment of Supply Chain Agility Using Fuzzy Logic for a Manufacturing Organization. IUP J. Supply Chain Manag. 2011, 8, 7-15.

60. Haider, H.; Hewage, K.; Umer, A.; Ruparathna, R.; Chhipi-Shrestha, G.; Culver, K.; Holland, M.; Kay, J.; Sadiq, R. Sustainability Assessment Framework for Small-Sized Urban Neighbourhoods: An Application of Fuzzy Synthetic Evaluation. Sustain. Cities Soc. 2018, 36, 21-32. [CrossRef]

61. Kammouh, O.; Noori, A.Z.; Taurino, V.; Mahin, S.A.; Cimellaro, G.P. Deterministic and Fuzzy-Based Methods to Evaluate Community Resilience. Earthq. Eng. Eng. Vib. 2018, 17, 261-275. [CrossRef]

62. Pham, T.Y.; Ma, H.M.; Yeo, G.T. Application of Fuzzy Delphi TOPSIS to Locate Logistics Centers in Vietnam: The Logisticians' Perspective. Asian J. Shipp. Logist. 2017, 33, 211-219. [CrossRef]

63. Seker, S.; Zavadskas, E.K. Application of Fuzzy DEMATEL Method for Analyzing Occupational Risks on Construction Sites. Sustainability 2017, 9, 2083. [CrossRef]

64. Prascevic, N.; Prascevic, Z. Application of Fuzzy AHP for Ranking and Selection of Alternatives in Construction Project Management. J. Civ. Eng. Manag. 2017, 23, 1123-1135. [CrossRef]

65. Ranganath, N.; Sarkar, D.; Patel, P.; Patel, S. Application of Fuzzy TOPSIS Method for Risk Evaluation in Development and Implementation of Solar Park in India. Int. J. Constr. Manag. 2020, 1-11. [CrossRef]

66. Emovon, I.; Okpako, O.S.; Edjokpa, E. Application of Fuzzy MOORA Method in the Design and Fabrication of an Automated Hammering Machine. World J. Eng. 2020, 18, 37-49. [CrossRef]

67. Christopher, M.; Towill, D. An Integrated Model for the Design of Agile Supply Chains. Int. J. Phys. Distrib. Logist. Manag. 2001, 31, 235-246. [CrossRef]

68. Vinodh, S.; Prakash, N.H.; Selvan, K.E. Evaluation of Agility in Supply Chains Using Fuzzy Association Rules Mining. Int. J. Prod. Res. 2011, 49, 6651-6661. [CrossRef]

69. Iskanius, P. An Agile Supply Chain for a Project-Oriented Steel Product Network; University of Oulu: Oulu, Finland, 2006; ISBN 978-951-42-8148-8.

70. Samizadeh, R.; Aghagoli, S.; Vatankhah, S. The Effect of IT Integration on Improving Agility, Integration and Performance of Supply Chain. Int. J. Adv. Oper. Manag. 2019, 11, 126-141. [CrossRef]

71. Wadhwa, S.; Mishra, M.; Saxena, A. A Network Approach for Modeling and Design of Agile Supply Chains Using a Flexibility Construct. Int. J. Flex. Manuf. Syst. 2008, 19, 410. [CrossRef]

72. Eshlaghy, A.; Ghatari, A.; Nikoomaram, H.; Zandhessami, H. Process Based Agile Supply Chain Model According to BPR and IDEF 3.0 Concepts. Contemp. Eng. Sci. 2009, 2, 117-138.

73. Tseng, Y.-H.; Lin, C.-T. Enhancing Enterprise Agility by Deploying Agile Drivers, Capabilities and Providers. Inf. Sci. 2011, 181, 3693-3708. [CrossRef]

74. Braunscheidel, M.J.; Suresh, N.C. The Organizational Antecedents of a Firm's Supply Chain Agility for Risk Mitigation and Response. J. Oper. Manag. 2009, 27, 119-140. [CrossRef]

75. Raj, S.A.; Jayakrishna, K.; Vimal, K.E.K. Modelling the Metrics of Leagile Supply Chain and Leagility Evaluation. Int. J. Agil. Syst. Manag. 2018, 11, 179-202. [CrossRef] 
76. Barutçu, S. Customized Products: The Integrating Relationship Marketing, Agile Manufacturing And Supply Chain Management For Mass Customization. Available online: https://www.semanticscholar.org/paper/Customized-Products\%3A-TheIntegrating-Relationship-Barut\%C3\%A7u/fc3a5bde8bb8c256cb893d912a0591abb67254ca (accessed on 18 January 2021).

77. Vinodh, S.; Aravindraj, S. Evaluation of Leagility in Supply Chains Using Fuzzy Logic Approach. Int. J. Prod. Res. 2013, 51, 1186-1195. [CrossRef]

78. Lin, C.-T.; Chiu, H.; Tseng, Y.-H. Agility Evaluation Using Fuzzy Logic. Int. J. Prod. Econ. 2006, 101, 353-368. [CrossRef]

79. Kovach, J.; Stringfellow, P.; Turner, J.; Cho, D.B.R. The House of Competitiveness: The Marriage of Agile Manufacturing, Design for Six Sigma, and Lean Manufacturing with Quality Considerations. J. Ind. Technol. 2005, 21, 10.

80. Zhang, Z.; Sharifi, H. A Methodology for Achieving Agility in Manufacturing Organisations. Int. J. Oper. Prod. Manag. 2000, 20, 496-513. [CrossRef]

81. Sherehiy, B.; Karwowski, W.; Layer, J.K. A Review of Enterprise Agility: Concepts, Frameworks, and Attributes. Int. J. Ind. Ergon. 2007, 37, 445-460. [CrossRef]

82. Avoine, G. Privacy Issues in RFID Banknote Protection Schemes. In Proceedings of the Smart Card Research and Advanced Applications VI; Quisquater, J.-J., Paradinas, P., Deswarte, Y., El Kalam, A.A., Eds.; Springer US: Boston, MA, USA, 2004 ; pp. 33-48.

83. Gunasekaran, A.; Lai, K.; Edwin Cheng, T.C. Responsive Supply Chain: A Competitive Strategy in a Networked Economy. Omega 2008, 36, 549-564. [CrossRef]

84. Kao, C.; Liu, S.-T. Fractional Programming Approach to Fuzzy Weighted Average. Fuzzy Sets Syst. 2001, 120, 435-444. [CrossRef]

85. Vinodh, S.; Vimal, K.E.K. Thirty Criteria Based Leanness Assessment Using Fuzzy Logic Approach. Int. J. Adv. Manuf. Technol. 2012, 60, 1185-1195. [CrossRef]

86. Guesgen, H.W.; Albrecht, J. Imprecise Reasoning in Geographic Information Systems. Fuzzy Sets Syst. 2000, 113, $121-131$. [CrossRef]

87. Degani, R.; Bortolan, G. The Problem of Linguistic Approximation in Clinical Decision Making. Int. J. Approx. Reason. 1988, 2, 143-162. [CrossRef]

88. Chen, S.-J.; Chen, S.-M. Fuzzy Risk Analysis Based on Measures of Similarity between Interval-Valued Fuzzy Numbers. Comput. Math. Appl. 2008, 55, 1670-1685. [CrossRef]

89. Chen, S.-J.; Hwang, C.-L. Fuzzy Multiple Attribute Decision Making: Methods and Applications; Lecture Notes in Economics and Mathematical Systems; Springer: Berlin/Heidelberg, Germany, 1992; ISBN 978-3-540-54998-7.

90. Lee-Kwang, H.; Lee, J.H. A Method for Ranking Fuzzy Numbers and Its Application to Decision-Making. IEEE Trans. Fuzzy Syst. 1999, 7, 677-685. [CrossRef]

91. Dahmardeh, N.; Pourshahabi, V. Agility evaluation in public sector using fuzzy logic. Iran. J. Fuzzy Syst. 2011, 8, 95-111. [CrossRef]

92. Nayagam, V.L.G.; Venkateshwari, G.; Sivaraman, G. Ranking of Intuitionistic Fuzzy Numbers. In Proceedings of the 2008 IEEE International Conference on Fuzzy Systems (IEEE World Congress on Computational Intelligence), Hong Kong, China, 1-6 June 2008; pp. 1971-1974. 